Development Of Homestay in Improving Tourism Visits in Toba Samosir District, Lumbanjulu District

\author{
${ }^{1}$ Politeknik Pariwisata Medan \\ Correspondence : Mustafa Kamal, Politeknik Pariwisata Medan \\ Email : mustafakamal@poltekparmedan.ac.id \\ DOI : https://doi.org/10.36983/japm.v8i2.67
}

Mustafa Kamal ${ }^{1}$

\begin{abstract}
The development of the tourism sector can encourage the income of the surrounding community due to the presence of attractions, as well as Homestay is a very lucrative destination for foreign exchange. Homestay development must be supported by good facilities and infrastructure for each area, so that guests who come and stay feel happy. In Toba Samosir Regency there are still many who do not understand the homestay and the guesthouse, where there are still many homestays that do not have the standard homestays that should be. Through this research the writer will conduct an analysis by conducting research and direct interviews with several workers, visitors, and homestay businesses in Toba Samosir Regency. Where this research uses descriptive methods, the results of this study are that the development of homestays can increase the level of visits, where the homestay here as one of the facilities that is more flexible and affordable.
\end{abstract}

Keywords : homestay development, tourism visit

\title{
Pengembangan Homestay dalam Peningkatan Kunjungan Wisata di Kabupaten Toba Samosir Kecamatan Lumbanjulu
}

\begin{abstract}
ABSTRAK
Pengembangan sektor pariwisata dapat mendorong pendapatan masyarakat sekitar dikarenakan adanya objek wisata,begitu juga dengan Homestay merupakan destinasi yang sangat menguntungkan bagi devisa negara. Pengembangan homestay harus di dukung adanya sarana dan prasarana yang baik bagi setiap daerah, agar para tamu yang datang dan menginap merasa senang. Di Kabupaten Toba Samosir masih banyak yang kurang memahami antara homestay dengan guesthouse, dimana masih banyak penamaan homestay yang tidak memiliki standar homestay yang seharusnya. Melalui penelitian ini penulis akan melakukan analisis dengan melakukan penelitian dan wawancara langsung dengan beberapa pekerja, pengunjung, dan pelaku usaha homestay yang ada di Kabupaten Toba Samosir. Dimana penelitian ini menggunakan metode kualitatif, adapun hasil dari penelitian ini adalah bahwa pengembangan homestay dapat meningkatkan tingkat kunjungan, dimana homestay disini sebagai salah satu fasilitas yang lebih fleksibel dan terjangkau.
\end{abstract}

Kata kunci : pengembangan homestay, kunjungan wisata 


\section{PENDAHULUAN}

\section{Latar Belakang Masalah}

Kabupaten Toba Samosir adalah sebuah kabupaten di Provinsi Sumatera Utara, Indonesia. Ibukotanya adalah Kota Balige. Kabupaten Toba Samosir merupakan satu dari tujuh kabupaten yang mengelilingi Danau Toba, yaitu danau terluas di Indonesia. Suku yang mendiami kabupaten ini pada umumnya adalah suku Batak Toba. Luas wilayah $2.352 \mathrm{~km}^{2}$, Provinsi Sumatera Utara, dan tanggal peresmian 9 Maret 1999. Sektor pariwisata merupakan sektor potensial yang dapat menjadi andalan di Kabupaten Toba Samosir. Jumlah Wisatawan yang datang ke Toba Samosir dapat menambah pendapatan masyarakat sekitarnya.

Sektor pariwisata di Indonesia menurut Santoso (2008) adalah salah satu sektor yang memegang peranan penting dalam keberlangsungan perekenomian Indonesia. Jika mendapatkan pengelolaan yang baik dan benar, pembangunan pariwisata sebagai salah satu industri akan menciptakan kemakmuran melalui perkembangan transportasi, akomodasi dan komunikasi yang menciptakan peluang kerja yang relatif besar. Pariwisata adalah salah satu jenis industri baru yang mampu mempercepat pertumbuhan ekonomi dan penyediaan lapangan kerja, peningkatan penghasilan, standar hidup serta menstimulasi sektor-sektor produktif lainnya. Industri pariwisata semakin dikembangkan oleh banyak negara karena memberikan manfaat ekonomi, termasuk Indonesia. Daerah-daerah di Indonesia berlomba mengembangkan kawasan wisata agar daerahnya menjadi salah satu daerah tujuan wisata. Potensi daerah dikembangkan menjadi objek wisata untuk ditawarkan kepada pengunjung wisatawan lokal maupun mancanegara.

Konsep pengembangan suatu wilayah dalam meningkatkan kunjungan wisata dapat dilihat melalui harapan dari daerah dalam memajukan peran untuk membenahi suatu kehidupan dari segi sosial, ekonomi, budaya, pendidikan dan kesejahteraan masyarakat. Pengaruh globalisasi, pasar bebas dan regionalisasi menyebabkan terjadinya perubahan dan dinamika sosial, dan ekonomi antarnegara, antardaerah (kota/kabupaten), kecamatan hingga perdesaan. Pengembangan suatu destinasi wisata yang kebanyakan di desa menjadi prioritas untuk membangun suatu desa dalam menunjang kesejahteraan bagi warag yang berada di sekitar objek wisata, dimana objek wisata ini menjadi tujuan penting dengan adanya akomodasi seperti homestay yang akan membuat pengunjung tidak jauh-jauh mencari penginapan, dimana semua kegiatan menjadi sangat dekat dikarenakan adanya homestay yang ada disekitar objek wisata.

Dimana pembangunan homestay juga akan mengurangi angka pengangguran yang ada di sekitar masyarakat. Seperti kebanyakan daerah wisata yang berada di desa yang terus memajukan daerahnya dengan membuat penginapan seperti homestay, dimana pembangunan homestay ini dapat dilihat dari keberadaan potensi pariwisata yang unik dan menarik di suatu daerah, sehingga dapat dimanfaatkan melalui pengembangan pariwisata yang baik.

\section{KERANGKA KONSEP}

\section{Kepariwisataan}

Pariwisata adalah berbagai macam kegiatan wisata yang didukung berbagai fasilitas serta layanan yang disediakan masyarakat, pengusaha, pemerintah, dan pemerintah daerah. Kepariwisataan berarti keseluruhan kegiatan yang terkait dengan pariwisata dan bersifat multidimensi serta multidisiplin, yang muncul sebagai wujud kebutuhan setiap orang dan Negara, serta 
interaksi antara wisatawan dan masyarakat setempat, sesama wisatawan, pemerintah daerah, dan pengusaha. Menurut Undangundang No. 10 Tahun 2009 Tentang Kepariwisataan, tujuan kepariwisataan yaitu meningkatkan pertumbuhan ekonomi, meningkatkan kesejahteraan rakyat, menghapus kemiskinan, mengatasi pengangguran, melestarikan alam, lingkungan, dan sumber daya, memajukan kebudayaan, menggangkat citra bangsa, memupuk rasa cinta tanah air, memperkukuh jati diri dan kesatuan bangsa, mempererat persahabat antar bangsa. Untuk mengembangkan kegiatan wisata, tujuan wisata harus memiliki :

a. Objek/atraksi dan daya tarik wisata;

b. Transportasi dan infrastruktur;

c. Akomodasi (tempat menginap);

d. Usaha makanan dan minuman;

e. Jasa pendukung lainnya seperti : biro perjalanan, cinderamata, informasi, pemandu, kantor pos, bank, penukaran uang, internet, wartel, pulsa, salon dan lain-lain, (Unesco, 2009)

\section{Definisi Pengembangan}

Pengembangan

mengisyaratkan suatu proses evolusi dengan konotasi positif atau sekurangkurangnya bermakna "Tidak Jalan Di Tempat" Sammeng (2000:227). Pengembangan adalah proses atau cara yang terjadi secara terus-menerus, untuk menjadikan sesuatu objek tersebut menjadi lebih baik sehingga dapat meningkatkan kebutuhan masyarakat secara keseluruhan. Pengembangan pariwisata bertujuan untuk memberikan keuntungan bagi wisatawan maupun komunitas tuan rumah. Dengan adanya pembangunan pariwisata diharapkan mampu meningkatkan taraf hidup masyarakat melalui keuntungan secara ekonomi yang dibawa ke kawasan tersebut. Dengan kata lain, pengembangan pariwisata melalui penyediaan fasilitas infrastruktur, wisatawan dan penduduk setempat akan saling diuntungkan.

Teknik Pengembangan Pariwisata

\section{Carrying capacity}

Teknik yang sering digunakan dalam pengembangan destinasi pariwisata adalah carrying capacity (daya dukung kawasan). Menurut Richardson dan Fluker (2004 :305 dalam Pitana dan Diarta 2009)

\section{Recreational Carrying Capacity (RCC)}

RCC diakui sebagai model utama dalam mengelola dampak akibat kunjungan wisatawan (Richardson dan Fluker, 2004 :310). Dampak dari pembangunan dan pengembangan destinasi wisata (baik tipe, lokasi, dan kualitasnya) pada lingkungan diteliti dan diidentifikasi tingkat kritisnya. Contohnya, tingkat kritis suatu destinasi wisata mengacu pada jumlah orang yang mengunjungi kawasan tersebut pertahun, perhari atau persekali kunjungan. Pada umumnya, nilai optimum kunjungan berkisar antara 10 sampai 20 persen di bawah jumlah maksimumnya.

\section{Tourism Opportunity Spectrum (TOS)}

Butler dan Waldbrook (1991 dalam Pitana, dan Diarta 2009) memperkenalkan teknik perencanaan ekowisata yang dikenal dengan Tourism Opportunity Spectrum (TOS). Elemen dalam konsep tersebut adalah aksesibilitas, dalam pengembangan pariwisata sebagai sebuah sistem, faktor aksesibilitas, baik berupa perencanaan perjalanan, penyediaan informasi mengenai rute dan destinasi, ketersediaan sarana transportasi, akomodasi, ataupun kemudahan lain untuk mencapai destinasi menjadi penentu berhasilnya peluang pengembangan pariwisata.

\section{Bentuk-Bentuk Pariwisata}

a. Resor

Salah satu betuk kegiatan pariwisata untuk liburan adalah jenis pengembangan resor. Resor menyediakan banyak fasilitas dan pelayanan wisata yang berkualitas tinggi.

\section{b. Pariwisata Kota}


Pariwisata kota ini banyak menawarkan atraksi wisata belanja, sejarah, dan budaya serta kehidupan kota.

c. Mice

Menurut Pendit (1999 :25), Mice diartikan sebagai wisata konvensi, perjalanan insentif, dan pameran merupakan usaha dengan kegiatan member jasa pelayanan bagi suatu pertemuan sekelompok orang (negarawan, usahawan, cendekiawan, dsb).

Faktor-faktor yang perlu diketahui dalam pengembangan pariwisata

Ada beberapa faktor yang perlu diketahui dalam pengembangan pariwisata, yaitu :

1. Wisatawan

2. Transportasi

3. Obyek dan daya tarik wisata

4. Fasilitas pelayanan

5. Infrastruktur pendukung

6. Masyarakat local

7. Informasi

\section{Pendekatan Pengembangan Pariwisata}

Ada 5 pendekatan pengembangan pariwisata yang perlu diketahui dan diaplikasikan dalam pembangunan dan pengembangan pariwisata, yaitu :

1. Pendekatan pemberdayaan masyarakat local;

2. Pendekatan berkelanjutan;

3. Pendekatan kesisteman;

4. Pendekatan kewilayahan;

5. Pendekatan dari sisi penawaran (supply)

Aspek 4A (Attraction, Accessibility, Amenities, Ancillary Service).

a. Attraction Menurut Suwena (2010: 88), atraksi atau obyek daya tarik wisata (ODTW) merupakan komponen yang signifikan dalam menarik kedatangan wisatawan. Hal yang dapat dikembangkan menjadi atraksi wisata disebut dengan modal atau sumber kepariwisataan (tourism resources).

Modal atraksi yang menarik kedatangan wisatawan ada tiga, yaitu :
1) Natural Resources (alami) seperti gunung, danau, pantai dan bukit;

2) atraksi wisata budaya seperti arsitektur rumah tradisional di desa, situs arkeologi, seni dan kerajinan, ritual, festival, kehidupan masyarakat sehari-hari, keramahtamahan, makanan; dan

3) atraksi buatan seperti acara olahraga, berbelanja, pameran, konferensi dan lain-lain. Modal kepariwisataan menurut Suwena (2010: 89) dapat dikembangkan menjadi atraksi wisata di tempat modal wisata ditemukan (in situ) dan di luar tempatnya yang asli (ex situ). Atraksi wisata dibedakan lagi menjadi atraksi penahan dan atraksi penangkap wisatawan.

a. Accessibility Menurut Sunaryo (2013: 173), aksesibilitas pariwisata dimaksudkan sebagai "segenap sarana yang memberikan kemudahan kepada wisatawan untuk mencapai suatu destinasi maupun tujuan wisata terkait". Menurut French dalam Sunaryo (2013: 173) menyebutkan faktor-faktor yang penting dan terkait dengan aspek aksesibilitas wisata meliputi petunjuk arah, bandara, terminal, waktu yang dibutuhkan, biaya perjalanan, frekuensi transportasi menuju lokasi wisata dan perangkat lainnya.

b. Amenities Sugiama (2011) menjelaskan bahwa amenitas meliputi "serangkaian fasilitas untuk memenuhi kebutuhan akomodasi (tempat penginapan), penyediaan makanan dan minuman, tempat hiburan (entertainment), tempat-tempat perbelanjaan (retailing) dan layanan lainnya". French dalam Sunaryo (2013: 173) memberikan batasan bahwa 
amenitas bukan merupakan daya tarik bagi wisatawan, namun dengan kurangnya amenitas akan menjadikan wisatawan menghindari destinasi tertentu.

c. Ancillary Service Sunaryo (2013: 159) menjelaskan ancillary service lebih kepada ketersediaan sarana dan fasilitas umum yang digunakan oleh wisatawan yang juga mendukung terselenggaranya kegiatan wisata seperti bank, ATM, telekomunikasi, rumah sakit dan sebagainya. Sedangkan Sugiama (2011) menjelaskan bahwa ancillary service mencakup keberadaan berbagai organisasi untuk memfasilitasi dan mendorong pengembangan serta pemasaran kepariwisataan destinasi bersangkutan.

\section{Kelembagaan Pariwisata}

\begin{tabular}{crr}
\multicolumn{2}{c}{ Kelembagaan } & \multicolumn{2}{c}{ kepariwisataan } \\
dijelaskan dalam & UU tentang
\end{tabular}
Kepariwisataan nomor 10 tahun 2009 sebagai "keseluruhan institusi pemerintah, baik pemerintah pusat maupun daerah, swasta dan masyarakat, sumberdaya manusia, mekanisme operasional serta regulasi yang terkait dengan kepariwisataan". Sunaryo (2013: 117) menjelaskan peran dan fungsi dari komponen pelaku usaha maupun pemangku kepentingan pengembangan kepariwisataan.

\section{Homestay}

Pada peraturan Pemerintah Nomor 50 Tahun 2011 tentang Rencana Induk Pembangunan Pariwisata Nasional tahun 2010 - 2025, usaha pariwisata didefinisikan sebagai usaha yang menyediakan barang dan/atau jasa bagi pemenuhan kebutuhan wisatawan dan penyelenggaraan pariwisata. Peraturan Menteri Pariwisata RI Nomor 25 tahun 2015 tentang Standar Usaha Motel, tidak mengungkap detail tentang usaha jasa akomodasi dalam bentuk homestay. Dalam
Undang-Undang No 10 Tahun 2009, usaha pariwisata adalah usaha yang menyediakan barang dan/ atau jasa bagi pemenuhan kebutuhan wisatawan dan penyelenggaraan pariwisata. Usaha pariwisata meliputi daya tarik wisata, kawasan pariwisata, jasa transportasi wisata, jasa perjalanan wisata, jasa makanan dan minuman, penyediaan akomodasi, penyelenggaraan kegiatan hiburan dan rekreasi, penyelenggaraan pertemuan (MICE), jasa informasi pariwisata, jasa konsultan pariwisata, jasa pramuwisata, wisata tirta dan spa. Homestay merupakan salah satu bentuk usaha jasa akomodasi, belum diatur secara eksplisit dalam peraturan terkait. Homestay menjadi peluang bisnis jasa yang baru yang mampu menggerakkan sektor bisnis lainnya, seperti penyewaan kendaraan, jasa parkir, jasa pemandu wisata, jasa binatu, dan cinderamata. Peluang bisnis homestay juga memberi lowongan pekerjaan baru dengan kebutuhan SDM yang juga berkompetensi dibidangnya.

Awalnya, homestay dikenal di Amerika digambarkan sebagai rumah kecil yang menjadi pelindung bagi petani dari cuaca. Homestay tersebut berbentuk rumah beratap ilalang, sangat sederhana dalam perlengkapan rumah tangga. Seiring dengan perkembangan waktu, homestay berubah menjadi sebuah bangunan penginapan sebagai tempat peristirahatan yang sangat menyenangkan bagi para pekerja (Kemenpar, 2016). Di Indonesia, homestay menjadi perhatian pemerintah sejak adanya program desa wisata melalui PNPM Mandiri Pariwisata yang diselenggarakan Kementerian Kebudayaan dan Pariwisata tahun 2009. Dalam pengembangan program desa wisata, homestay merupakan bagian dari daya tarik wisata yang didapatkan oleh wisatawan dalam kunjungannya ke desa wisata.

Dalam pengertian lainnya, sebuah homestay dengan kata-kata gabungannya (homestay) tinggal di rumah seseorang sebagai tamu yang membayar untuk jangka 
waktu singkat. Tamu disediakan akomodasi dan layanan oleh keluarga maupun secara individu (pelayan) dalam homestay. Homestay umumnya dibangun di daerah perdesaan (rural destination) dengan upaya menarik wisatawan yang telah datang ke daerah perkotaan (urban destination) dengan menawarkan suasana lingkungan alam perdesaan, akomodasi yang nyaman, aktivitas selama tinggal di homestay, makanan yang terjaga kebersihannya serta harga yang bersaing sesuai dengan fasilitas yang disediakan. Homestay menawarkan pengalaman unik dan menarik, dengan pengalaman belajar dengan lingkungan serta berinteraksi sosial dengan masyarakat. Tak jarang dalam kegiatan wisatawan di homestay, para wisatawan menganggap tuan rumah pemilik usaha akomodasi sebagai saudara angkat mereka. Kenyamanan dan rasa kekeluargaan yang diciptakan dalam melakukan kegiatan wisata di homestay menjadi bagian kenangan wisatawan.

Homestay merupakan salah satu upaya pengembangan dalam peningkatan kunjungan wisatawan. Perubahan teknologi secara tidak langsung akan merubah perilaku wisatawan dalam menentukan destinasi pilihannya. Kecepatan teknologi, informasi dan komunikasi di era jaman digital akan memberikan warna bagi kebutuhan wisatawan. Untuk menyikapi kesiapan destinasi dalam bentuk homestay, pengelola destinasi harus menyiapkan fasilitas dan infrastruktur yang memenuhi kriteria. Pengelolaan homestay masa kini, tidaklah berarti meninggalkan budaya masa lalu. Namun pengelolaan homestay yang diharapkan adalah pengelolaan usaha bisnis akomodasi yang tidak melupakan kecanggihan teknologi dalam setiap produk yang ditawarkan. Pariwisata adalah industri yang menjual cerita. Kemasan cerita menarik masa lampau yang menggunakan kecanggihan teknologi, akan menarik minat wisatawan maupun pengunjung untuk datang ke destinasi, khususnya ke akomodasi dalam bentuk homestay. Kunjungan wisatawan yang datang ke homestay, memberi dampak bagi pemberdayaan masyarakat lokal dan memberi keberlanjutan.

Pengembangan homestay di suatu destinasi. Tidak dapat dipungkiri besarnya keterlibatan masyarakat setempat sangat berpengaruh pada keberhasilan pemanfaatan homestay sebagai penunjang akomodasi di destinasi. Melalui homestay yang dikelola sendiri oleh masyarakat maka ide-ide segar bagi pengembangan homestay maupun pengembangan peran serta masyarakat dalam pengembangan destinasi menjadi lebih mudah untuk dilaksanakan. Oleh sebab itu

pelatihan dan peningkatan kapasistas serta kapabilitas masyarakat dalam pengelolaan homestay harus terus dilakukan.

\section{METODOLOGI}

Penelitian ini dilakukan dengan menggunakan metode deskriptif. Analisis data hasil kuesioner. Metode yang digunakan dalam penelitian menggunakan pendekatan kualitatif. Hal ini dilakukan untuk mengetahui konsep pengembangan homestay dalam meningkatkan kunjungan wisata. Menurut Bogdan dan Taylor dalam Moleong (2004;3) metodologi kualitatif sebagai prosedur penelitian yang menghasilkan data deskriptif berupa katakata tertulis atau lisan dari orang-orang dan perilaku yang dapat diamati. Teknik pengumpulan data dalam penelitian ini adalah Survei, Penyebaran kuesioner/wawancara, Observasi lapangan, dan kepustakaan.

Survei yang dilakukan oleh peneliti langsung ke tempat lokasi di Toba Samosir Kecamatan Lumbanjulu. Peneliti memperoleh data yang sebenarnya dengan melakukan terjun langsung ke lapangan untuk melakukan survei dan pembagian kuesioner. autentik, obyektif, dan jujur 
dimana berasal dari sumber data (responden) secara langsung. Peneliti melakukan survei melalui kuesioner maupun wawancara kepada pemilik homestay ataupun tamu yang menginap di homestay. Adapun data tambahan melalui wawancara langsung dengan beberapa pengunjung dan pekerja di salah satu homesta. Peneliti juga menggunakan teknik kepustakaan di dalam melaksanakan penelitian.

\section{HASIL DAN PEMBAHASAN}

\section{Gambaran Umum}

Homestay merupakan suatu tempat wisata yang dijadikan sebagai rumah singgah atau tempat peristirahatan sejenak. Dimana homestay yang terdapat di Kabupaten Toba Samosir Kecamatan Lumbanjulu perlu dilakukan penyuluhan kepada pengelola homestay tentang strategi dalam pengelolaan yang benar sesuai dengan fungsi homestay itu sendiri, sehingga pelayanan terhadap wisatawan dapat menarik tingkat kunjungan wisatawan yang datang menginap di homestay tersebut.

$$
\text { Pengembangan homestay }
$$

diperlukan adanya suatu sarana dan prasarana yang baik. Faktor pendukung atraksi wisata, aksebilitas, dan amenitas merupakan pendukung wisatawan. Memanfatkan homestay sebagai suatu bentuk akomodasi yang murah dan aman, serta dapat memfasilitasi wisatawan bergaul dengan masyarakat setempat, dan menikmati kearifan lokal yang dianggap unik dan mengesankan. Para pengelola homestay jika memungkinkan dapat diajak ke daerah yang sudah maju pengelolaan homestay, sehingga dapat dijadikan studi banding dari mereka.

Berikut ini akan diuraikan hasil penelitian yang dilakukan di Kabupaten Toba Samosir Kecamatan Lumbanjulu dengan melakukan wawancara dan pengisian angket penelitian ke beberapa responden pemilik homestay dan sebahagian tamu, dan data tersebut akan dilakukan dengan analisa desktriptif.

Tabel Tanggapan responden yang pernah mendapatkan penyuluhan tentang pengelolaan Homestay

\begin{tabular}{|c|l|c|c|}
\hline No & Frekuensi & $\begin{array}{c}\text { Jumlah } \\
\text { (orang) }\end{array}$ & $\mathbf{( \% )}$ \\
\hline 1 & Tidak Pernah & 35 & 87,5 \\
\hline 2 & Pernah & 5 & 12,5 \\
\hline \multicolumn{2}{|l|}{ Jumlah } & $\mathbf{4 0}$ & $\mathbf{1 0 0}$ \\
\hline
\end{tabular}

Sumber : data diolah, 2019

Tabel diatas dapat dibuat suatu analisa bahwa yang pernah mendapatkan penyuluhan tentang pengelolaan homestay, hanya sekitar $(12,5 \%)$ berjumlah 5 orang, dan yang merasa bahwa tidak pernah mendapatkan penyuluhan sebanyak (87,5\%) dengan jumlah 35 orang. Dengan demikian, diharapkan dapat dilakukan penyuluhan tentang pengelolaan homestay yang baik untuk daerah Kabupaten Toba Samosir Kecamatan Lumnanjulu.

Tabel Tanggapan responden tentang pentingkah suatu proses perencanaan dalam mengembangkan Homestay

\begin{tabular}{|c|l|c|c|}
\hline No & Frekuensi & $\begin{array}{c}\text { Jumlah } \\
\text { (orang) }\end{array}$ & $\mathbf{( \% )}$ \\
\hline 1 & Tidak Penting & 13 & 10 \\
\hline 2 & Penting & 27 & $\begin{array}{c}13,3 \\
4\end{array}$ \\
\hline \multicolumn{2}{|l|}{ Jumlah } & $\mathbf{4 0}$ & $\mathbf{1 0 0}$ \\
\hline
\end{tabular}

Sumber : data diolah, 2019

Tabel diatas dapat dibuat suatu analisa bahwa yang berpendapat tentang pentingnya suatu proses perencanaan dalam mengembangkan homestay, hanya sekitar $(13,34 \%)$ berjumlah 27 orang, dan yang berpendapat bahwa tidak penting sebanyak (10\%) dengan jumlah 13 orang.

Dengan demikian, diharapkan dapat dilakukan suatu proses perencanaan dalam melakukan pengembangan homestay, agar maksud dan tujuan dalam membangun homestay dapat tercapai sehingga menarik 
wisatawan untuk datang kembali ke daerah Kabupaten Toba Samosir Kecamatan Lumbanjulu.

Tabel Tanggapan responden tentang
mengetahui suatu teknik dalam
mengembangkan Homestay
\begin{tabular}{|c|l|c|c|}
\hline No & Frekuensi & $\begin{array}{c}\text { Jumlah } \\
\text { (orang) }\end{array}$ & $(\boldsymbol{\%})$ \\
\hline 1 & Tidak Mengetahui & 33 & 82,5 \\
\hline 2 & Mengetahui & 7 & 17,5 \\
\hline Jumlah & $\mathbf{4 0}$ & $\mathbf{1 0 0}$ \\
\hline
\end{tabular}

Sumber : data diolah, 2019

Tabel diatas dapat dibuat suatu analisa bahwa yang mengetahui suatu teknik dalam mengembangkan homestay, hanya sekitar $(17,5 \%)$ berjumlah 7 orang, dan yang tidak mengetahui teknik dalam mengembangkan homestay sebanyak $(82,5 \%)$ dengan jumlah 33 orang. Dengan demikian, diharapkan dapat dilakukan suatu pengetahuan tentang teknik dalam mengembangkan homestay agar pemilik usaha homestay dapat menerapkan teknik tersebut demi kemajuan usahanya dan khususnya untuk daerah Kabupaten Toba Samosir Kecamatan Lumbanjulu.

\section{Tabel Tanggapan responden tentang mengetahui suatu bentuk dalam mengembangkan pariwisata}

\begin{tabular}{|c|l|c|c|}
\hline No & Frekuensi & $\begin{array}{c}\text { Jumlah } \\
\text { (orang) }\end{array}$ & $(\mathbf{\%})$ \\
\hline 1 & Tidak Mengetahui & 38 & 95 \\
\hline 2 & Mengetahui & 2 & 5 \\
\hline \multicolumn{2}{|l}{ Jumlah } & $\mathbf{4 0}$ & $\mathbf{1 0 0}$ \\
\hline
\end{tabular}

Sumber : data diolah, 2019

Berdasarkan Tabel diatas dapat dibuat suatu analisa bahwa yang mengetahui suatu bentuk dalam mengembangkan pariwisata, hanya sekitar (5\%) berjumlah 2 orang, dan yang tidak mengetahui bentuk dalam mengembangkan pariwisata sebanyak (95\%) dengan jumlah 38 orang. Dengan demikian, diharapkan dapat dilakukan suatu pengetahuan tentang bentuk dalam mengembangkan pariwisata agar kemajuan pariwisata di Indonesia semakin banyak dikunjungi oleh wisatawan di daerah Kabupaten Toba Samosir Kecamatan Lumnanjulu.

Tabel Tanggapan responden tentang usaha homestay dapat meningkatkan kunjungan wisatawan

\begin{tabular}{|c|l|c|c|}
\hline No & Frekuensi & $\begin{array}{c}\text { Jumlah } \\
\text { (orang) }\end{array}$ & $\mathbf{( \% )}$ \\
\hline 1 & $\begin{array}{l}\text { Tidak dapat } \\
\text { meningkatkan } \\
\text { kunjungan }\end{array}$ & 9 & 22,5 \\
\hline 2 & $\begin{array}{l}\text { Dapat } \\
\text { Meningkatkan } \\
\text { Kunjungan }\end{array}$ & 31 & 77,5 \\
\hline \multicolumn{2}{|l|}{ Jumlah } & $\mathbf{4 0}$ & $\mathbf{1 0 0}$ \\
\hline
\end{tabular}

Sumber : data diolah, 2019

Berdasarkan Tabel diatas dapat dibuat suatu analisa bahwa usaha homestay dapat meningkatkan kunjungan wisatawan, hanya sekitar $(77,5 \%)$ berjumlah 31 orang, dan yang mengatakan usaha homestay tidak dapat meningkatkan kunjungan wisatawan sebanyak $(22,5 \%)$ dengan jumlah 9 orang. Dengan demikian, diharapkan usaha homestay masyarakat di daerah Kabupaten Toba Samosir Kecamatan Lumnanjulu dapat lebih baik agar dapat meningkatkan kunjungan wisatawan.

Tabel Tanggapan responden tentang wisatawan asing yang menginap

\begin{tabular}{|c|l|c|c|}
\hline No & Frekuensi & $\begin{array}{c}\text { Jumlah } \\
\text { (orang) }\end{array}$ & $\mathbf{( \% )}$ \\
\hline 1 & Tidak ada & 23 & 57,5 \\
\hline 2 & Ada & 17 & 42,5 \\
\hline \multicolumn{2}{|l|}{ Jumlah } & $\mathbf{4 0}$ & $\mathbf{1 0 0}$ \\
\hline
\end{tabular}

Sumber : data diolah, 2019

Berdasarkan Tabel diatas dapat dibuat suatu analisa bahwa wisatawan asing yang menginap di homestay hanya sekitar $(42,5 \%)$ berjumlah 17 orang, dan yang mengatakan tidak ada wisatawan asing yang menginap sebanyak $(57,5 \%)$ dengan jumlah 23 orang. Dengan demikian, diharapkan wisatawan asing banyak yang 
datang dan menginap di homestay yang terdapat pada daerah Kabupaten Toba Samosir Kecamatan Lumnanjulu dapat lebih baik agar dapat meningkatkan kunjungan wisatawan.

Tabel Tanggapan responden tentang konsep homestay

\begin{tabular}{|c|l|c|c|}
\hline No & Frekuensi & $\begin{array}{c}\text { Jumlah } \\
\text { (orang) }\end{array}$ & $(\boldsymbol{\%})$ \\
\hline 1 & Tidak mengetahui & 34 & 85 \\
\hline 2 & Mengetahui & 6 & 15 \\
\hline Jumlah & $\mathbf{4 0}$ & $\mathbf{1 0 0}$ \\
\hline
\end{tabular}

Sumber : data diolah, 2019

Berdasarkan Tabel diatas dapat dibuat suatu analisa bahwa pemilik homestay yang mengetahui konsep homestay pengembangan wisata pedesaan dan perkotaan berdasarkan peraturan pemerintah No.50 tahun 2011 hanya sekitar $(15 \%)$ berjumlah 6 orang, dan yang mengatakan tidak mengetahui sebanyak (85\%) dengan jumlah 34 orang. Dengan demikian, diharapkan pemilik homestay mengetahui tentang konsep homestay berdasarkan peraturan pemerintah yang disebutkan tentang rencana induk pembangunan kepariwisataan Nasional tahun 2010-2025 sebagai daya tarik wisata budaya antara lain wisata perkotaan dan pedesaan, selain itu wisata sejarah dan religi, serta kuliner, seni dan tradisi yang terdapat pada Kabupaten Toba Samosir Kecamatan Lumnanjulu.

Tabel Tanggapan responden tentang melayani tamu yang menginap

\begin{tabular}{|c|l|c|c|}
\hline No & Frekuensi & $\begin{array}{c}\text { Jumlah } \\
\text { (orang) }\end{array}$ & $(\boldsymbol{\%})$ \\
\hline 1 & Tidak Baik & 0 & 0 \\
\hline 2 & Baik & 40 & 100 \\
\hline \multicolumn{2}{|l}{ Jumlah } & $\mathbf{4 0}$ & $\mathbf{1 0 0}$ \\
\hline
\end{tabular}

Sumber : data diolah, 2019

Berdasarkan Tabel diatas dapat dibuat suatu analisa bahwa pemilik homestay dalam melayani tamu yang menginap baik (100\%) berjumlah 40 orang, dan yang mengatakan tidak baik sebanyak $(0 \%)$. Dengan demikian, diketahui bahwa para pemilik homestay selalu berusaha bersikap baik terhadap tamu yang menginap dalam melayani, agar para tamu merasa puas terhadap pelayanan homestay pada Kabupaten Toba Samosir Kecamatan Lumnanjulu.

Tabel Tanggapan responden tentang kearifan lokal yang telah diterapkan

\begin{tabular}{|c|l|c|c|}
\hline No & Frekuensi & $\begin{array}{c}\text { Jumlah } \\
(\text { orang) }\end{array}$ & $(\boldsymbol{\%})$ \\
\hline 1 & Tidak diterapkan & 10 & 25 \\
\hline 2 & Diterapkan & 30 & 75 \\
\hline \multicolumn{2}{|l|}{ Jumlah } & $\mathbf{4 0}$ & $\mathbf{1 0 0}$ \\
\hline
\end{tabular}

Sumber : data diolah, 2019

Berdasarkan Tabel diatas dapat dibuat suatu analisa bahwa pemilik homestay yang telah menerapkan kearifan lokal terhadap wisatawan sekitar $(75 \%)$ berjumlah 30 orang, dan yang belum menerapkan sebanyak (25\%) dengan jumlah 10 orang. Dengan demikian, adanya kearifan lokal suatu daerah dengan daya tarik khas dan adanya interaksi langsung dengan masyarakat setempat membuat wisatawan masa kini lebih menyukai.

Tabel Tanggapan responden tentang kategori tamu yang menginap Di homestay

\begin{tabular}{|c|l|c|c|}
\hline No & Frekuensi & $\begin{array}{c}\text { Jumlah } \\
\text { (orang) }\end{array}$ & $(\boldsymbol{\%})$ \\
\hline 1 & Individu & 24 & 60 \\
\hline 2 & Kelompok & 16 & 40 \\
\hline Jumlah & $\mathbf{4 0}$ & $\mathbf{1 0 0}$ \\
\hline
\end{tabular}

Sumber : data diolah, 2019

Berdasarkan Tabel diatas dapat dibuat suatu analisa bahwa pemilik homestay banyak dikunjungi oleh tamu dengan kategori individu sekitar (60\%) berjumlah 24 orang, dan yang dikunjungi dengan kategori kelompok sebanyak (40\%) dengan jumlah 16 orang. Dengan demikian, pemilik homestay mengetahui bahwa wisatawan yang datang ke homestay lebih 
banyak dengan kategori individu dari pada kategori kelompok.

Tabel Tanggapan responden tentang mendapatkan bantuan sarana dan prasarana dari Pemerintah

\begin{tabular}{|c|l|c|c|}
\hline No & Frekuensi & $\begin{array}{c}\text { Jumlah } \\
\text { (orang) }\end{array}$ & $(\boldsymbol{\%})$ \\
\hline 1 & Tidak Mendapatkan & 32 & 80 \\
\hline 2 & Mendapatkan & 8 & 20 \\
\hline Jumlah & $\mathbf{4 0}$ & $\mathbf{1 0 0}$ \\
\hline
\end{tabular}

Sumber : data diolah, 2019

Berdasarkan Tabel diatas dapat diketahui pemilik homestay yang mendapatkan bantuan sarana dan prasarana dari Pemerintah setempat sekitar (20\%) berjumlah 8 orang, dan yang tidak mendapatkan bantuan sebanyak (80\%) dengan jumlah 32 orang. Dengan demikian, pemilik usaha homestay harusnya dapat dukungan dari Pemerintah setempat berupa bantuan sarana dan prasarana agar dapat meningkatkan kunjungan wisatawan Kabupaten Toba Samosir Kecamatan Lumbanjulu.

Tabel Tanggapan responden tentang homestay dapat meningkatkan kunjungan wisata

\begin{tabular}{|c|l|c|c|}
\hline No & Frekuensi & $\begin{array}{c}\text { Jumlah } \\
\text { (orang) }\end{array}$ & $\mathbf{( \% )}$ \\
\hline 1 & Tidak dapat & 7 & 17,5 \\
\hline 2 & Dapat & 33 & 82,5 \\
\hline Jumlah & $\mathbf{4 0}$ & $\mathbf{1 0 0}$ \\
\hline
\end{tabular}

Sumber : data diolah, 2019

Berdasarkan Tabel diatas dapat diketahui tentang homestay yang dapat meningkatkan kunjungan wisata menurut para pemilik homestay sekitar $(82,5 \%)$ berjumlah 33 orang, dan yang mengatakan tidak sebanyak $(17,5 \%)$ dengan jumlah 7 orang. Dengan demikian, homestay yang dimiliki dengan kriteria yang diharapkan oleh para wisata dapat meningkatkan kunjungan wisata, meskipun ada sebahagian pemilik homestay yang tidak terlalu mengerti tentang manfaat dari tingkat kunjungan wisata agar dapat penyuluhan untuk para pemilik homestay pada Kabupaten Toba Samosir Kecamatan Lumbanjulu.

Tabel Tanggapan responden tentang membangun homestay lebih mudah dan lebih fleksibel dibandingkan membangun hotel

\begin{tabular}{|c|l|c|c|}
\hline No & Frekuensi & $\begin{array}{c}\text { Jumlah } \\
\text { (orang) }\end{array}$ & $\mathbf{( \% )}$ \\
\hline 1 & Tidak & 3 & 7,5 \\
\hline 2 & Ya & 37 & 92,5 \\
\hline \multicolumn{2}{|l|}{ Jumlah } & $\mathbf{4 0}$ & $\mathbf{1 0 0}$ \\
\hline
\end{tabular}

Sumber : data diolah, 2019

Berdasarkan Tabel diatas dapat diketahui pemilik homestay mengakui bahwa membangun homestay lebih mudah dan lebih fleksibel dibandingkan membangun hotel sekitar (92,5\%) berjumlah 37 orang, dan yang mengatakan tidak sebanyak $(7,5 \%)$ dengan jumlah 3 orang. Dengan demikian, pemilik usaha homestay akan mendapatkan kemudahan dan lebih fleksibel dalam membangun homestay di Kabupaten Toba Samosir Kecamatan Lumbanjulu.

\section{PENUTUP}

\section{Simpulan}

1.Pengembangan homestay dalam meningkatkan kunjungan wisatawan merupakan salah satu cara realistis untuk memenuhi kebutuhan wisata sebagai salah satu fasilitas pendukung suatu destinasi di Kabupaten Toba Samosir Kecamatan Lumbanjulu.

2. Dengan adanya homestay dapat meningkatkan kunjungan wisata di Kabupaten Toba Samosir Kecamatan Lumbanjulu.

3. Membangun homestay lebih mudah dan lebih fleksibel dibandingkan membangun sebuah hotel. 


\section{Saran}

1. Adanya kegiatan penyuluhan tentang pengelolaan homestay terhadap pemilik homestay, agar dapat memahami konsep homestay yang semestinya;

2. Adanya bantuan ataupun perhatian Pemerintah bagi pelaku usaha homestay dalam bentuk sarana dan prasarana di Kabupaten Toba Samosir Kecamatan Lumbanjulu.

3. Adanya homestay sebagai rumah inap bagi wisata, diharapkan dapat menonjolkan kearifan lokal suatu daerah dengan daya tarik khas di Kabupaten Toba Samosir Kecamatan Lumbanjulu;

\section{UCAPAN TERIMA KASIH}

Penulis mengucapkan terima kasih kepada Bapak Direktur Politeknik Pariwisata Medan atas bantuan dan dukungannya, sehingga penelitian ini dapat diterbitkan di jurnal ini.

\section{DAFTAR PUSTAKA}

Bogdan dan Taylor. (1975). Metodologi Penelitian Kualitatif. Bandung: Remadja Karya.

Sammeng, Andi M. (2000). Cakrawala Pariwisata. Alfabeta. Bandung. Missing: (2000:227). $\quad$ Must include: (2000:227).

Sunaryo, Bambang. 2013. Kebijakan Pembangunan Destinasi Pariwisata Konsep dan Aplikasinya di Indonesia. Yogyakarta : Gava Media.

Sugiama, A Gima (2011), Ecotourism: Pengembangan Pariwisata Berbasis Konservasi Alam, Guardaya Intimarta, Bandung.

Undang-Undang No 10 Tahun 2009 Tentang Kepariwisataan.

UNESCO. Intangible Cultural Heritage: UNESCO, 2009.

\section{Biodata Penulis:}

Mustafa Kamal, S.Sos, M.Hum adalah dosen dengan jabatan lektor kepala pada Politeknik Pariwisata Medan. 